Tomasz Konopka ${ }^{1}$, Marcin Strona ${ }^{1}$, Dorota Księżniak-Baran², Dominika Wojton ${ }^{2}$

\title{
Uduszenie workiem foliowym w materiale Zakładu Medycyny Sądowej w Krakowie
}

Plastic bag suffocation in material collected by Department of Forensic Medicine in Krakow

1 Z Katedry i Zakładu Medycyny Sądowej Uniwersytetu Jagiellońskiego Collegium Medicum Kierownik Katedry: prof. dr hab. n. med. M. Kłys

2 Ze Studenckiego Koła Naukowego przy Katedrze Medycyny Sądowej Uniwersytetu Jagiellońskiego Collegium Medicum

Przypadki zgonów w wyniku uduszenia przez założenie na głowę worka foliowego, są bardzo rzadkie. W krakowskim Zakładzie Medycyny Sądowej w ostatnich 20 latach, badano czternaście, jednak ich liczba wyraźnie wzrasta, sięgając kilku przypadków rocznie. Śmierć w tym mechanizmie jest trudna diagnostycznie, a często zdarza się, że jedynym śladem wskazującym na tę przyczynę zgonu, jest obecność worka na głowie.

Cases of death resulting from placing a plastic bag on the victim,s head are very rare. In the last 20 years, in the Department of Forensic Medicine in Krakow, there were fourteen such cases examined. Their number is, however, noticeably growing, amounting to as many as few cases per year. Death resulting from this mechanism is difficult from the diagnostic point of view and often the only indicative evidence is a presence of a plastic bag on the head.

Słowa kluczowe:

uduszenie workiem foliowym, samobójstwo

Key words:

plastic bag suffocation, suicide

\section{WPROWADZENIE}

Przypadki śmierci w wyniku uduszenia przez założenie na głowę worka foliowego, są bardzo rzadkie. W krakowskim Zakładzie Medycyny Sądowej w ostatnich kilku latach badane są 1-2 przypadki rocznie, jednak w kolejnych latach można spodzie- wać się wzrostu liczby tego typu zgonów. Ze statystyk międzynarodowych wynika, że w państwach Europy zachodniej i Ameryki Północnej ten sposób popełnienia samobójstwa jest coraz częstszy, zwłaszcza w grupie osób po 70-tym roku życia. Śmierć w tym mechanizmie jest trudna diagnostycznie, często zdarza się, że jedynym śladem wskazującym na tę przyczynę zgonu, jest obecność worka na głowie.

\section{CEL PRACY}

Celem pracy jest ustalenie sekcyjnych objawów śmierci przez uduszenie workiem foliowym, przydatnych w opiniowaniu sądowo-lekarskim.

\section{MATERIA $Ł$ I METODA}

Zebrano przypadki zgonów w wyniku uduszenia przez założenie na głowę worka foliowego, badane w krakowskim Zakładzie Medycyny Sądowej w latach 1994-2013. Przeanalizowano ślady stwierdzane w czasie sekcji, wyniki badań toksykologicznych, okoliczności śmierci, a także porównano je z danymi pochodzącymi z piśmiennictwa sądowo-lekarskiego.

\section{WYNIKI}

W latach 1994-2013 w krakowskim Zakładzie Medycyny Sądowej było badanych 14 przypadków śmierci w wyniku uduszenia workiem foliowym. We wszystkich przypadkach poza jednym (przypadek 12), ofiarami byli mężczyźni. Worki foliowe były bar- 
dzo różne - z przezroczystej folii polietylenowej, worki na śmieci, torby reklamowe, co najmniej dwukrotnie badano zwłoki z założonymi na głowę dwoma workami. Sposób mocowania worka na szyi też był bardzo zróżnicowany - od luźnego zawinięcia pod szyją, przez zawiązanie samego worka, po obwiązywanie go na szyi sznurkiem. W jednym przypadku (kobieta w depresji poporodowej znaleziona martwa pod łóżkiem na oddziale psychiatrycznym) worek nie obejmował całej głowy, a jedynie był owinięty wokół szyi i dolnej części twarzy, zakrywając usta i nos. W części przypadków do badania dostarczano zwłoki bez worka i bez informacji jak był założony.

Zestawienie zebranych przypadków przedstawia tabela 1.

W przypadkach $11,13,14$, oprócz worka foliowego na głowie, założona była instalacja w postaci rurki z tworzywa sztucznego dostarczającej gaz z butli, w jednym przypadku był to hel, w dwóch pozostałych rodzaju gazu nie udało się ustalić. W przypadku nr 8 obok zwłok leżał pojemnik na gaz do zapalniczek.

W dwóch przypadkach, na ciele zmarłego stwierdzono obecność skrępowań, w przypadku 7. zwłoki były przywiązane do łóżka za ręce, w przypadku 10. obie ręce były spięte $z$ tyłu opaskami samozaciskającymi.

Wybroczyny w spojówkach były obecne w sześciu przypadkach, ślady na szyi w postaci odgniecenia w skórze lub przynajmniej zaczerwienienia w sześciu, przy czym przypadki z obydwu tych grup nie pokrywały się ze sobą. Mniej charakterystyczne ślady, takie jak wybroczyny pod błonami surowiczymi wystąpiły w pięciu przypadkach, ostre rozdęcie płuc tylko w jednym. W czterech przypadkach nie wystąpił żaden z objawów uznawanych za typowe dla uduszenia gwałtownego.

\section{DYSKUSJA}

Jakkolwiek pierwsze przypadki uduszenia workiem gumowym zostały odnotowane jeszcze w okresie międzywojennym [1], to jednak za początek tego rozdziału w medycynie sądowej uznać należy rok 1957, kiedy folia polietylenowa została wprowadzona do masowej produkcji. Już dwa lata później The Times pisał o zgonach 20, dzieci które w ciągu jednego roku zmarły w USA wskutek udu- szenia przezroczystymi torebkami foliowymi, bawiąc się w kosmonautów [2]. W roku 1960 ukazała się pierwsza publikacja opisująca przypadki uduszenia workiem foliowym w trakcie czynności autoerotycznych [3], a w 1962 pierwsze opisy samobójstw popełnionych tą metodą [4]. Do rozpowszechnienia tego sposobu pozbawienia życia, mógł przyczynić się popularny film Stanleya Donena z 1963 roku - „Szarada”, ukazujący scenę zabójstwa dokonanego przez założenie ofierze na głowę torebki foliowej. Na pewno natomiast gwałtowny wzrost liczby przypadków w ostatnich 30 latach, jest efektem propagowania tej metody (jako najmniej bolesnego sposobu odebrania sobie życia) przez stowarzyszenia działające na rzecz legalizacji tzw. wspomaganego samobójstwa (assisted suicide) np. Hemlock Society. W książce Final Exit, wydanej przez to Towarzystwo w 1991 roku, zalecono m.in. właśnie popełnianie samobójstwa przez założenie na głowę torby foliowej, obwiązanej na szyi gumką lub rajstopami, po uprzednim zażyciu leku uspokajającego [6]. W kolejnych wydaniach metodę uzupełniono zaleceniem podawania do torby gazu wypierającego powietrze, np. helu. W Stanach Zjednoczonych ta metoda popełnienia samobójstwa jest spotykana coraz częściej, przy czym wybierana jest głównie przez osoby starsze [5].

Śmierć w wyniku uduszenia workiem foliowym, to w przeważającej większości samobójstwa. W publikacji Jonesa analizującej 30 przypadków z okresu 15 lat w Szkocji, samobójstwa wykazano w 27 [6]. W publikacji Byarda, analizującej 45 przypadków badanych w okresie 20 lat w Adelaide w Australii, samobójstwa wystąpiły w 42 [7]. Z kolei na 53 przypadki badane w okresie 10 lat w Seattle w USA, wszystkie stanowiły samobójstwa [5]. Zgony o charakterze nieszczęśliwych wypadków i zabójstw, opisywane najczęściej jako case report, nie przekraczają 10\% wszystkich zgonów w wyniku uduszenia workiem foliowym.

W grupie wypadków można wyróżnić trzy rodzaje działań zagrażających śmiercią - przypadkowe uduszenie dzieci, zgony w trakcie czynności autoerotycznych i zgony związane z odurzaniem. Przypadki uduszenia dzieci w trakcie zabawy, stosunkowo częste na początku ery torebek foliowych, obecnie stały się bardzo rzadkie, zapewne za sprawą działań uświadamiających to niebezpieczeństwo i zamieszczania ostrzeżeń na opakowaniach. Nieco 
Tabela 1. Zestawienie przypadków uduszenia workiem foliowym.

Table 1. Listing of cases of plastic bag suffocation.

\begin{tabular}{|c|c|c|c|c|}
\hline & Rok / Year & Wiek / Age & Wyniki sekcji zwłok / Autopsy results & Wynik badań toksykologicznych / Toxicology results \\
\hline 1. & 1995 & 29 & $\begin{array}{l}\text { - wybroczyny tylko pod opłucną } \\
\text { - obrzęk płuc } \\
\text { - blood extravasations seen solely under the pleura } \\
\text { - pulmonary edema }\end{array}$ & $\begin{array}{l}\text { - fenobarbital poniżej stężenia toksycznego } \\
\text { - alkohol ujemny } \\
\text { - phenobarbital below toxic levels } \\
\text { - alcohol negative }\end{array}$ \\
\hline 2. & 1999 & 47 & $\begin{array}{l}\text { - okrężne odciśnięcie na szyi } \\
\text { - pojedyncze wybroczyny w spojówkach } \\
\text { - wybroczyny pod opłucną } \\
\text { - obrzęk płuc } \\
\text { - circular impressions on the neck } \\
\text { - blood extravasations in the conjunctivas } \\
\text { - blood extravasations under the pleura } \\
\text { - pulmonary edema }\end{array}$ & $\begin{array}{l}\text { - fenobarbital w stężeniu śmiertelnym } \\
\text { - phenobarbital in lethal concentration }\end{array}$ \\
\hline 3. & 2000 & 45 & $\begin{array}{l}\text { - obrzęk i ostre rozdęcie płuc } \\
\text { - pulmonary edema and acute distension }\end{array}$ & $\begin{array}{l}\text { - alkohol we krwi 1,4\%o, w moczu 0,7\%。 } \\
\text { - blood alcohol 1.4\%o, urine alcohol 0.7\%。 }\end{array}$ \\
\hline 4. & 2002 & 70 & $\begin{array}{l}\text { - okrężne odciśnięcie na szyi } \\
\text { - circular impression on the neck }\end{array}$ & $\begin{array}{l}\text { - alkohol i toksykologia ujemne } \\
\text { - alcohol and toxicology negative }\end{array}$ \\
\hline 5. & 2003 & 27 & $\begin{array}{l}\text { - obrzęk płuc } \\
\text { - wybroczyny pod nasierdziem } \\
\text { - pulmonary edema } \\
\text { - blood extravasations under the epicardium }\end{array}$ & $\begin{array}{l}\text { - alkohol i toksykologia ujemne } \\
\text { - alcohol and toxicology negative }\end{array}$ \\
\hline 6. & 2007 & 15 & $\begin{array}{l}\text { - pasmo zaczerwienienia na szyi } \\
\text { - reddened band-like mark on the neck }\end{array}$ & $\begin{array}{l}\text { - alkohol i toksykologia ujemne } \\
\text { - alcohol and toxicology negative }\end{array}$ \\
\hline 7. & 2007 & 22 & $\begin{array}{l}\text { - okrężne odciśnięcie na szyi } \\
\text { - circular impression on the neck }\end{array}$ & $\begin{array}{l}\text { - alkohol ujemny } \\
\text { - alcohol negative }\end{array}$ \\
\hline 8. & 2007 & 28 & $\begin{array}{l}\text { - płytkie odgniecenie na szyi } \\
\text { - obfite wybroczyny w spojówkach, skórze twarzy i klatki piersiowej } \\
\text { - masywne zachłyśnięcie wymiocinami } \\
\text { - shallow impression on the neck } \\
\text { - profound blood extravasations involving the conjunctivas } \\
\text { facial skin and chest } \\
\text { - massive aspiration of vomit matter }\end{array}$ & $\begin{array}{l}\text { - alkohol we krwi 1,6\%o, w moczu 2,4\%o } \\
\text { - toksykologia - propan i butan } \\
\text { - blood alcohol } 1.6 \% \text {, urine alcohol } 2.4 \% \text { o } \\
\text { - toxicology - propane and butane }\end{array}$ \\
\hline 9. & 2009 & 24 & $\begin{array}{l}\text { - wybroczyny w spojówkach } \\
\text { - blood extravasations in the conjunctivas }\end{array}$ & $\begin{array}{l}\text { - alkohol ujemny } \\
\text { - toksykologia - paracetamol w stężeniu terapeutycznym } \\
\text { - alcohol negative } \\
\text { - toxicology - paracetamol in therapeutic concentration }\end{array}$ \\
\hline 10. & 2010 & 33 & $\begin{array}{l}\text { - obfite wybroczyny w spojówkach, skórze głowy i klatki piersiowej } \\
\text { - profound blood extravasations involving the conjunctivas, skin } \\
\text { of the head and chest }\end{array}$ & $\begin{array}{l}\text { - alkohol we krwi } 2,8 \% \text {, w moczu } 4,5 \% \text { o } \\
\text { - toksykologia ujemna } \\
\text { - blood alcohol } 2.8 \% \text {, urine alcohol } 4.5 \% \text { o } \\
\text { - toxicology negative }\end{array}$ \\
\hline 11. & 2010 & 24 & $\begin{array}{l}\text { - wybroczyny w spojówkach } \\
\text { - pasmo zaczerwienienia na szyi } \\
\text { - wybroczyny pod opłucną } \\
\text { - blood extravasations in the conjunctivas } \\
\text { - reddened band-like mark on the neck } \\
\text { - blood extravasations under the pleura }\end{array}$ & $\begin{array}{l}\text { - alkohol ujemny } \\
\text { - alcohol negative }\end{array}$ \\
\hline 12. & 2011 & 25 & $\begin{array}{l}\text { - niewielki obrzęk płuc } \\
\text { - stan po niedawno przebytym porodzie } \\
\text { - slight pulmonary edema } \\
\text { - status post recent delivery }\end{array}$ & $\begin{array}{l}\text { - leki psychiatryczne w stężeniach terapeutycznych } \\
\text { - psychiatric medications in therapeutic concentrations }\end{array}$ \\
\hline 13. & 2012 & 32 & $\begin{array}{l}\text { - niewielki obrzęk płuc } \\
\text { - slight pulmonary edema }\end{array}$ & $\begin{array}{l}\text { - alkohol ujemny } \\
\text { - ślad metabolitu THC } \\
\text { - alcohol negative } \\
\text { - traces of THC metabolite }\end{array}$ \\
\hline 14. & 2013 & 31 & $\begin{array}{l}\text { - wybroczyny w spojówkach } \\
\text { - wybroczyny pod nasierdziem } \\
\text { - blood extravasations in the conjunctivas } \\
\text { - blood extravasations under the epicardium }\end{array}$ & $\begin{array}{l}\text { - alkohol ujemny } \\
\text { - alcohol negative }\end{array}$ \\
\hline
\end{tabular}


częściej spotykane są zgony niemowląt zaplątanych w folię znajdującą się w łóżeczku lub stanowiącą część odzieży [7]. Czynności autoerotyczne o charakterze podduszania, najczęściej realizowane są drogą kontrolowanego zadzierzgnięcia lub podwieszania, ale spotykane są także przypadki duszenia przez owijanie głowy folią z tworzywa sztucznego, prowadzące sporadycznie do skutku śmiertelnego $[8,6]$. Na rozpoznanie tego typu działań wskazuje obecność pornografii w pobliżu zwłok, rozebranie do naga lub przebranie w damską bieliznę. Równie rzadkie są przypadkowe zgony w trakcie odurzania się substancjami lotnymi, np. acetonem lub chloroformem, kiedy ofiara dla uniknięcia strat substancji odurzającej, aplikuje ją sobie do worka założonego na głowę [6].

Zabójstwa dokonane przez założenie na głowę ofiary worka z tworzywa sztucznego, są jeszcze rzadsze, możliwe do zrealizowania dopiero po skrępowaniu lub uśpieniu ofiary. Opis uduszenia w ten sposób dwójki dzieci w wieku 9 i 11 lat podaje Byard [7]. W materiale krakowskiego Zakładu Medycyny Sądowej przewinęły się dwa przypadki zabójstwa dokonanego $w$ ten sposób. W pierwszym, trzy kobiety zaplanowały zabójstwo partnera jednej z nich, zrealizowane przez dodanie mu do jedzenia leku nasennego, a następnie uduszenie torbą foliową [9]. W drugim przypadku, kobieta podała swemu partnerowi piwo zaprawione lekiem nasennym, a następnie założyła mu na głowę worek na śmieci powodując zgon [10]. Niestety w żadnej z tych spraw nie udało się zbadać śladów pozostawianych przez ten sposób zabójstwa, ponieważ w pierwszym przypadku sprawczynie rozkawałkowały zwłoki i wrzuciły do zbiornika wodnego (głowy nie odnaleziono). W drugim przypadku sprawczyni zakopała zwłoki pod podłogą drewnianego domu, a po ujawnieniu zabójstwa po trzech latach, badano już tylko szkielet.

Intencją podjęcia niniejszego tematu, było ustalenie na jak największej liczbie przypadków - zmian sekcyjnych pozwalających na rozpoznanie uduszenia workiem foliowym jako przyczyny zgonu. Inspiracją do podjęcia tego tematu był przypadek 6 , w którym zwłoki do badania dostarczono już po zdjęciu worka z głowy, bez poinformowania o tym obducentów. Sekcja zwłok i badanie toksykologiczne wypadły zupełnie ujemnie, a nikły ślad na szyi sugerował szczątkową bruzdę wisielczą i dopiero z nadesłanych akt biegli dowiedzieli się, że chłopiec $w$ chwili znalezienia przez rodzinę, miał założoną na głowę torebkę foliową. Niestety jak wykazała analiza przedstawionych powyżej spraw, w sporej części z nich nie pojawiły się żadne jednoznaczne zmiany, a najbardziej charakterystyczny dla duszenia objaw - wybroczyny w spojówkach, wystąpił tylko w 6 spośród 14 badanych przypadków. Inne zmiany, np. ślady na szyi, wybroczyny pod błonami surowiczymi i ostre rozdęcie płuc są już zmianami dużo mniej charakterystycznymi.

Porównując te wyniki z obserwacjami odnotowanymi w innych publikacjach stwierdzić należy, że w większych zbiorach te charakterystyczne objawy występowały jeszcze rzadziej. W cytowanych powyżej publikacjach, wybroczyny w spojówkach stwierdzano tylko w 5-15\% zgonów w wyniku uduszenia workiem foliowym. Wysuwane jest zresztą przypuszczenie, że wybroczyny w spojówkach pojawiały się, nie jako wynik odcięcia dopływu tlenu przez folię, ale jako wyraz okrężnego zaciśnięcia szyi materiałem uszczelniającym worek - gumką, sznurkiem, taśmą samoprzylepną [5]. Niewykluczone zresztą, że w przypadkach z wybroczynami, jako mechanizm zgonu działało (lub współdziałało) zadzierzgnięcie. Co prawda siła z jaką założone było uszczelnienie była zazwyczaj niewielka, a w żadnym z badanych przypadków nie stwierdzono wewnętrznych obrażeń szyi, jednak do zaciśnięcia żył szyjnych wystarcza nacisk nawet tylko 2kG [11]. Tętnice w tej sytuacji pozostają co prawda drożne, jednak zamknięcie żył uniemożliwia powrót żylny, prowadząc do przerwania krążenia mózgowego i zastoju żylnego, ze wszystkimi jego konsekwencjami. Być może zatem w przypadkach bez wybroczyn działał jedynie mechanizm duszenia przez brak tlenu w powietrzu oddechowym, a w przypadkach z wybroczynami, dołączał mechanizm zagardlenia. Na podstawie samych tylko oględzin torby założonej na szyi, nie da się określić z jaką siłą była zaciśnięta. Także badanie śladów na szyi niewiele wnosi, bo we wszystkich analizowanych przypadkach były to ślady stosunkowo skąpe, nie różniące się od uciśnięcia spowodowanego kołnierzykiem koszuli.

Ciekawy rezultat dają wyniki badań toksykologicznych przeprowadzanych w przypadkach samobójstw przez uduszenie workiem foliowym. W publikacjach zagranicznych podkreślany jest duży 
odsetek spraw, w których stwierdza się wysoki poziom leków działających depresyjnie na ośrodkowy układ nerwowy. W publikacji Haddixa (53 przypadki z USA), obecność leków stwierdzono w 22 przypadkach, w tym w 12 w stężeniu toksycznym [5]. W publikacji Byarda (45 przypadków, Szkocja), leki stwierdzono w organizmach 27 ofiar, w tym u 17 z nich stężenie było toksyczne lub śmiertelne [7]. W materiale własnym, wysokie stężenia leków stwierdzono w dwóch przypadkach, w tym w jednym, w stężeniu spotykanym w zatruciach śmiertelnych (ostatnio pełne badanie toksykologiczne zlecane było rzadko). Tak wysokie dawki leków u ofiar samobójstw popełnionych tą metodą, wynikają zapewne z zaleceń książki autora Final Exit, aby przed popełnieniem samobójstwa zażyć dużą dawkę leku nasennego. Ponadto w części przypadków, zażycie dużej dawki leku może wynikać z zamiaru dokonania samobójstwa kombinowanego. Należy o tym pamiętać przy rozważaniu wersji zabójstwa przez uśpienie ofiary i uduszenie workiem - znalezienie wysokiej dawki leku psychotropowego nie jest jeszcze dowodem wskazującym na działanie drugiej osoby.

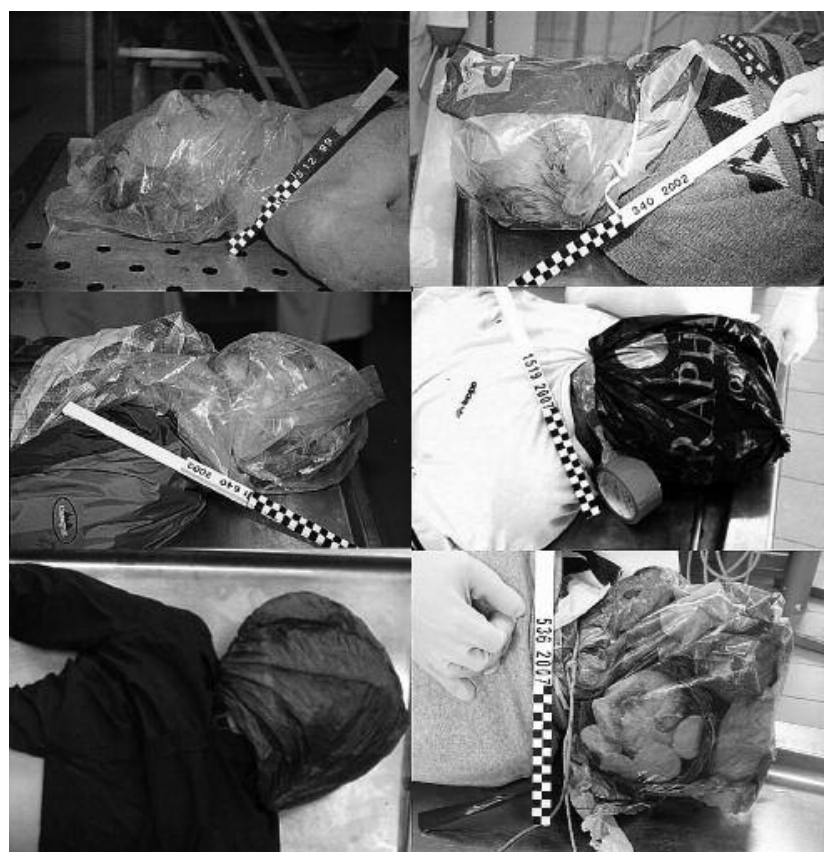

Ryc. 1. Uduszenia workiem foliowym.

Fig. 1. Plastic bag suffocation.

\section{WNIOSKI}

1. Samobójstwo przez uduszenie workiem foliowym założonym na głowę, może nie spowodować powstania zmian sekcyjnych charakterystycznych dla śmierci z uduszenia, a wynik sekcji zwłok może być całkowicie ujemny.

2. Badanie toksykologiczne ofiar samobójstw dokonanych tą metodą, często wykazuje obecność leków działających depresyjnie na OUN, nawet w stężeniach śmiertelnych.

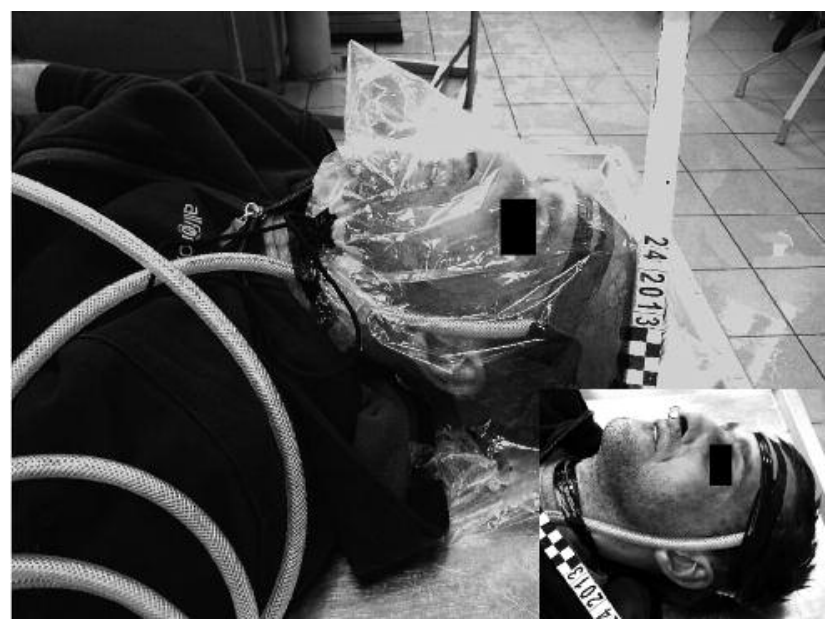

Ryc. 2. Przypadek 14, wąż doprowadzający hel pod worek foliowy.

Fig. 2. Case 14, a tube supplying helium under the plastic bag.

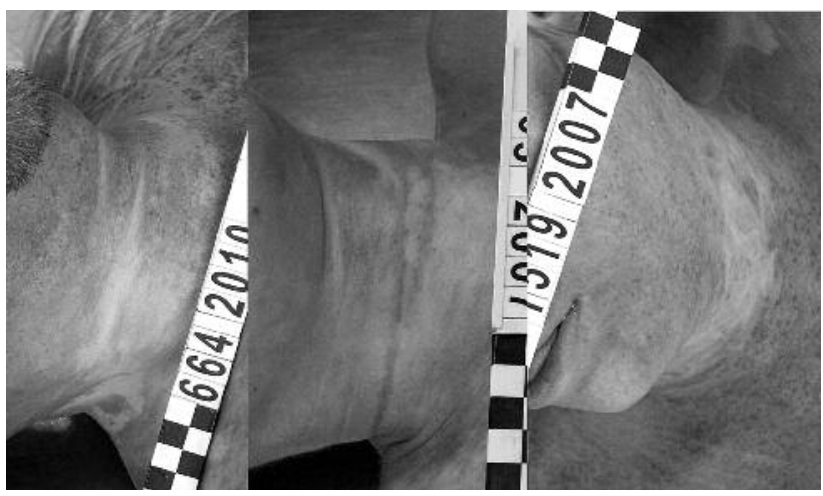

Ryc. 3. Ślady na szyi z przypadków uduszenia workiem foliowym.

Fig. 3. Marks on the neck from cases of plastic bag suffocation. 


\section{PIŚMIENNICTWO}

1. Prokop O.: Lehrbuch der gerichtlichen Medizin. Berlin 1960.

2. Robertson R. P.: Plastic bags. Br Med J, 1959; June 6: 1478.

3. Johnstone J. M., Hunt A. C., Milford E.: PlasticBag asphyxia in adults. Br Med J, 1960: 1714-1715.

4. Hunt A. C., Camps F. E.: Plastic-bag suicide. Br Med J, 1962, Feb 10: 378.

5. Haddix T. L., Harruff R. C., Reay D. T., Haglunf W. D.: Asphyxial suicides using plastic bags. Am J Forensic Med. Pathol; 1996, 17(4): 308-311.

6. Jones L. S., Wyatt J. P., Busuttil A.: Plastic bag asphyxia in Southeast Scotland. Am J Forensic Med Pathol; 2000, 21(4): 401-405.

7. Byard R. W., Simpson E., Gilbert J. D.: Temporal trends over the past two decades in asphyxial deaths in South Australia involving plastic bags or wrapping. J Clin Forensic Med; 2006, 13: 9-14.

8. Gross A.: Uduszenie gwałtowne $w$ trakcie czynności autoerotycznych. Arch. Med. Sąd. Kryminol. 1999, 49(2): 95-101.

9. Konopka T., Strona M., Bolechała F., Kunz J.: Corpse dismemberment in the material collected by the Department of Forensic Medicine, Cracow, Poland. Legal Medicine, 2007, 9(1): 1-13.

10. Konopka T., Kaczor E., Gross A., Bolechała F., Woźniak K., Strona M., Moskała A.: Zabójstwa sprzed lat, badane we współpracy z Policyjnym Archiwum X. Annales Academiae Medicinae Stetinensis; 2007, 53, Suppl. 2: 13-16.

11. DiMaio V. J., DiMaio D.: Medycyna Sądowa. Wydanie polskie pod redakcją B. Świątek i Z. Przybylskiego. Wrocław 2003. 